\title{
The neighbourhood imperative in the sustainable city
}

\author{
W. Humber \& T. Soomet \\ Centre for the Built Environment, Seneca College, Canada
}

\begin{abstract}
The idea of the neighbourhood describes more intimate local places in the contemporary city but it remains an illusive and therefore contested term with less use than it might have in creating more sustainable cities. It is depicted as one of the more significant foundations for building greater equity in the distribution of public resources and social capital, even as the "Not In My Backyard" (NIMBY) syndrome often paralyzes public action through community disengagement from larger obligations. Its contradictory nature reflects its place in everyday life as, on the one hand, defined by its familiarity and special distinction to residents, but on the other as a commodity for the real estate industry and individual property owners. The real contested character of the neighbourhood however makes it the ideal setting for examining, experimenting with, and implementing a coherent program of sustainability. This paper examines the modern character of the neighbourhood, its roots in garden cities, its three distinct formations, and the challenge to its authenticity as either no more than a sentimental abstraction with no social meaning or one whose limited legitimacy is undermined by continuing privatization and the hyper technological connectivity of individual life. The neighbourhood is a place that can support more indigenous economies, sustainable technologies and infrastructure, and genuine forms of public participation, as part of the renewal of contemporary cities.
\end{abstract}

Keywords: governance, city regions, infrastructure, creative city, social capital, regeneration, new urbanism, neighbourhood, NIMBY, sustainability.

\section{Nature of the modern world and the city}

We live in an urbanizing world. General estimates place urban residence as the living place of $60 \%$ of the world's population and this figure could reach $70 \%$ by 
mid century. World population will, given current trends and expectations, continue to grow from its 6.5 billion figure to over 9 billion by 2050 (Scientific American [1]) before it begins a gradual decline.

The idea of the city, particularly in North America, is evolving within a megapolitan region stretching over a hundred miles from historic city centres and within which formerly quasi independent small towns are now micropolitan places sharing all of the interests, jobs, and car dependency of the jurisdictionally defined big city, the borders of which are often 80 or more kilometres away. Governance structures at both the municipal and state/provincial level are struggling to adapt to this reality (Courchene [2]).

There are as well contesting ideas as to the appropriate future direction of these city regions. Urban development has moved away from central city, walkable, and traditional neighbourhood places, to an economy based on dispersed, decentralized industry, non-fixed path transportation and living places as commodities (Johns [3], Rae [4]). The flow of capital investment to places with good rates of return often doesn't conform to concerns for social equity or environmental health. (Donald [5]) Logistics management, in which "just in time" delivery is based on low wage production, cheap transportation and, at the end of that chain, product sale in a big box store, is wedded to car dependency and threatens traditional main street survival.

The ideas below describe the developed world, but they have relevance for the developing world where odd combinations of primitive infrastructure, alongside advanced electronics, and inhabitants' newness of residency and hence likelihood of living beside strangers, partake more of a modern world of neighbourhoods than a familiar and ancient residential lifestyle.

\section{Origins of the modern idea of the neighbourhood}

Contemporary social critics acknowledge the historic distinction of the modern city. More often their attention is focused on programs and policies at a macro level; nevertheless the local or neighbourhood level has been a scene of action for some.

In the $19^{\text {th }}$ century the Neighbourhood or Settlement House best represented social service delivery, based at the geographic level of the inner city. Other reformers however were less sanguine about the possibilities of inner city improvement and while accepting the neighbourhood as an idealized representation of persons living and working within close proximity of each other, they saw this occurring in newly designed communities on the edge of the old city.

Ebenezer Howard's concept of the neighbourhood as a founding piece of new garden city communities was an explicit acknowledgement of this geographic entity's legitimacy. (Hall and Ward [6]) Clarence Perry further developed it in his work for the Regional Plan of New York in 1929 and in his 1939 book, Housing for the Machine Age. His neighbourhood unit contained about 5,000 people and conformed to the size required to support at least one elementary school within reasonable walking distance of most children. 


\subsection{Critics of the neighbourhood idea}

Despite this apparent legitimisation of the neighbourhood idea, our locationspecific concept is more often rooted in sentimental attachments, personal impressions and our conflicted sense of the value of place. Critics question whether the neighbourhood has any real meaning as an entity connecting geographic space with social life (Gandy [7], Pahl, [8]).

Such criticism might appear, from a historical perspective, to be odd. The nearby residence of persons in a relatively stable location, a defining feature of the modern neighbourhood idea, has been a major characteristic of the evolution of human living from nomadic to settled existence. Our contemporary idea of the neighbourhood however has limited application to earlier forms of nearby living. Those places had a much different history, economic reality, and complexity of living arrangements, with personal ties based on kinship and survival. Premodern mobility, as well confined most humans to lifetime residence within a few miles of their birthplace.

\subsection{Contemporary features of the neighbourhood}

Our modern idea of the neighbourhood is rooted in the rise of a property owning middle class for whom a home has been their largest investment. Its protection and the enhancement of its value are major features of their security and wealth accumulation (Hayden [9]). This has bred a "Not in My Backyard" (NIMBY) attitude among many homeowners, who often unite in neighbourhood connection only in reaction to external threats, such as a new development or crime. The property industry furthered this evolution by defining value as a factor of location to which neighbourhood branding by use of a name and its implied identity gave further definition and meaning.

The neighbourhood idea accordingly remains confused and contested. It lacks, in most cases, any formal governance definition. Modern living in the developed world, and most often the desired goal of developing countries, is towards a lifestyle of consumption in which private cars go off to work, or shopping for even a jug of milk, or driving the kids to school. Public encounter is sacrificed to increasingly private lives in isolated recreation and media rooms. Low residential densities and a lack of street connectivity have eroded the possibility of other forms of mobility including public transit, and walking to nearby places. These precious enclaves with no noxious uses, and a single use identity, bereft even of small stores and other non-harmful functions, are a product of increasingly restrictive zoning. Children and the elderly whose lives are limited by a lack of car access and the restricted radius of safe walking are marginalized residents of dead streets. The hyper connectivity of modern technology from cell phones and iPods to blackberries enhances the privatizing character of everyday life.

\section{A new neighbourhood model}

The neighbourhood has three significant features - as a social unit, as a spatial unit, and as a network of relationships and patterns of use (Chaskin [10], 
Keller [11]). The question of its value for policy initiatives and environmental intervention however is also important. Recent literature supports its validity as an emerging focus for these issues (Bradford [12], Katz [13]).

\subsection{Creative cities and social capital}

Diversity, tolerance, and artistic variety are key attributes of such a focus in the emerging idea of the creative city (Florida [14]). Such cities require intriguing, differentiated mixed-use neighbourhoods with retail, residential and other uses. As well the social and economic consequences of declining social capital (Putnam [15]) are increasingly associated with lifestyles driven by urban sprawl, and reduced attention to neighbourhood connection.

There is increasing recognition as well of the significance of place in achieving greater social equity. Often this is as simple as investigating the level of public services delivered in a particular neighbourhood as opposed to a more affluent one. Organizations liked the United Way [16] in Toronto have defined the neighbourhood as an organizing setting for social intervention. Regeneration strategies throughout the world focus on rebuilding local institutions and improving the quality of the urban experience through better public spaces, as well as pursuing private investment in shopping options from grocery stores to second hand shops.

\subsection{Social equity and the lives of children}

The lives of children are either constrained or enhanced by the opportunities within their reasonable walking distance, and neighbourhoods are recognized as a venue of either good or bad health outcomes for all ages (Epstein [17]). While residents need access to the full employment and lifestyle possibilities of the greater city region, for many people the nearness of such opportunities is important for personal considerations (avoidance of car dependency and associated cost) public health (walking), family (social capital), and environmental (air quality).

\section{The neighbourhood in the building of sustainable cities}

Neighbourhood features have environmental consequences. The use of the neighbourhood idea for instance as a founding principle of modern urban planning influenced, for better or worse, suburban places built in the immediate post war era. More recently, the planning philosophy of the Congress for the New Urbanism, along with a rating system for neighbourhoods, currently being developed through the LEED (Leadership in Energy and Environmental Design) accreditation process, reflect a greater attention to the environmental impact of neighbourhood design.

\subsection{The pedestrian dimension}

At the root of a neighbourhood's authenticity is its most fundamental feature, namely that for most human living the walking distance of residents has been a 
key element in community design. A 400 to 800 meter radius, within which residents are prepared to walk for 5 to 10 minutes, depending on attractions and purpose, has universality. People do walk longer distances, or drive around the corner for small errands, but the distance cited is an existential piece of preferred human physical tolerance. It is significant in the design and our experience of the urban world.

Not surprisingly traditional cities throughout history have grown as a series of "urban quarters" of around 800 meters, in diameter, or about 40 hectares (Hardy [18]). They generally consist of a place of worship, town meeting hall, market, school and public buildings.

\subsection{The shared commons}

The local neighbourhood is as close to a sense of shared commons many will experience. The roads, verges, parks, even lighting and infrastructure, are shared attributes which in combination with memory, personal connection and informal encounter, as well as urban sensations as simple as the light at certain times of the day, burning leaves in the fall, the sound of a train whistle, and other shared experiences, sights and references, make up what might be described as a metaphysics of place.

\subsection{Neighbourhood types}

The neighbourhood's real value may be its future use as a significant aspect of sustainable cities. No matter how bleak or dreary, its familiarity in a large, cruel world, supports its evolving possibilities. By describing the main types of neighbourhood structure, we may determine their appropriate environmental role.

\subsubsection{The street neighbourhood}

The "street neighbourhood" (Jacobs [19]) describes those closest to one's residence. In a traditional, largely residential neighbourhood it is those living places on one's street or within a few blocks perhaps numbering 250 residences or fewer, and no more than 500 to 1,500 residents, depending on area densities. In an apartment it might be those on one's floor, though such settings have their own dynamics, which are beyond the scope of this paper.

It is of a size that persons can maintain casual and often recognizable encounters with others. It is at a level at which people are most comfortable providing assistance to each other. Decisions can generally be reached on common issues. It is based on co-operation in advocating a particular interest for an area. It is walkable, knowable, and provides the opportunity for many eyes to be on the street. Finally, essential services may be nearby, though in single use low-density subdivisions this is unlikely.

\subsubsection{The neighbourhood unit}

The next order of magnitude is the neighbourhood unit. It might average between 64 to 80 hectares, a substantial, though not overwhelming walking breadth of 
shared space (with the exception of the needs of mobility-challenged adults and small children). Individuals generally experience a multitude of such neighbourhood units for which the concept of the "roving neighbourhood" is applied (Riemer [20]). One unit may contain a school, another retail and still another, medical services. All of this depends on the level of mixed use available in any one unit.

\subsubsection{The neighbourhood district}

The final order is the neighbourhood district, generally beyond a walking distance size. It may be home to over 10,000 people, and often as many as 100,000 or more, most of whom are strangers to each other. Along with residential uses it has commercial and citywide amenities. It is often known as a destination for tourists or for those from other parts of the city region. Its distinct geographic identity is based on a name, a history, and positive or negative associations. It is of a size sometimes sufficient to have a basic governance structure or political representation. While it may best describe the public understanding of what a neighbourhood is for outsiders, in some ways it is the most sentimental and least real to its residents, except as a branded commodity, which improves the sale value of a property, or as an income-defined territory for social intervention.

\section{Integrating the environment with the civic and economic}

Each of these neighbourhood types is an organizing setting within the evolving city region, whose size, economic integration, and befuddling character, requires a more intimate connection. Each type can be allied with new ideas of civic inclusiveness, economic diversity, and environmental innovation to create a tripartite model of successful sustainability.

\subsection{Civic implications}

At the civic level the changing character of urban governance, as in some ways more important than the nation state and in virtually all cases more significant than the state/provincial level, finds an emerging need for regional/megapolitan governing structures to handle issues of mobility, energy use, and water quality protection. Such structures however are even further removed from the everyday understanding and connection of citizens. The neighbourhood in all three of its forms provides an opportunity for experimenting with different styles of more intimate and local authority, while generating awareness of broader obligations beyond a "Not In My Backyard" exclusivity.

\subsection{Economic implications}

Economically the integration of global economies, the increasing concentration of sectors like retail among fewer alternatives, and the sprawl inducing features of logistics management, create their own counter reaction of underground economies and community-based activities. These may have short lives or 
struggle to survive but they continue to appear and occasionally flourish. They respond to our market interest in diversity, new ideas, and individual initiative. Third places (Oldenberg [21]) in local communities, despite the prevalence of home electronic entertainment, or the homogenizing aspect of regional entertainment and shopping, speak to our need for familiar encounter, convivial spots for dining and drinking, and places for sharing information and access to new services and products.

\subsection{Environmental implications}

The neighbourhood is at the service of environmental opportunity. It is a key observation of proponents of the Congress of the New Urbanism (Duany et al [22]) that settling the issue of human habitability may be the most important piece for renewing environmental health. The argument can be summarized as follows - to the extent we find satisfaction in our living places, confront the continuing privatization in our lives, measure the matters that are meaningful to healthy families and friendships, and limit our dependence on cars, global resources (with their impact on local places far away) and excessive consumerism, we will tackle environmental quality.

The ways of addressing these issues have often been disconnected from daily lives except for small measures like weekly recycling. In combination with civic participation and economic inventiveness however they provide for a confrontation of ideas in which cost savings from greater energy efficiency are not an excuse for larger homes or commuting longer distances to work. Designing locally for human scale (Sale [23]) provides for personal comfort, a sense of shared intimacy, a place for meaningful encounters, and the ability to reinforce and expand social capital.

\section{The neighbourhood opportunity}

Residing as it does between individual initiatives, which are often undone by other lifestyle choices, and broader public and private initiatives conflicted by contradictory policy measures, the neighbourhood is the local place in which the essence of community initiatives are starkly revealed. They are the place in which our ideas of responsibility and obligation for others either geographically separate from us, or for those who will inherit the world we build, are most real and explicit.

\subsection{Technology tools}

Emerging forms of technological infrastructure, particularly hybrid and green options, are one opportunity for a neighbourhood imperative. Local wastewater treatment, renewable, local, and demand-driven energy initiatives can operate at a disaggregated level (Moffatt [24]). They provide work opportunities, the chance to enliven and broaden the kinds of uses within walking distance, and a new set of facilities potentially managed by some form of neighbourhood governance. These measures are applicable in both developed and developing 
countries and allow for decentralization and distribution of resources downward to those using such resources.

These kinds of places broaden public choice beyond those which are aesthetically dull, environmentally harmful, dangerous to health, and lack the kind of spirited animation of historically successful and vibrant places.

\subsection{Personal considerations}

Walkability is a primary focus for a neighbourhood planning respecting sustainability. Mixed uses, street connectivity, and regard for human scale and safety contribute to a renewed public health strategy, countering the car's dominating presence. Beneficiaries include children and others without private transport or accessible public transit. Success requires engaging emergency service providers in thinking beyond wide streets.

\section{Renewing the neighbourhood imperative}

There are at least four possible outcomes for a renewed neighbourhood imperative. The first is market driven as privatizing communication technologies create opportunities for local connection, or as new products (locally grown food) and services (home delivery and neighbourhood retail) make this imperative the preferred choice. The second is imposed, as environmental degradation and depleted energy sources force market transformation and government action, either by targeted taxation or strategic use of resources for best end uses, thus forcing people to work and shop closer to home. In the third, fear or antipathy to outsiders, perceived threats from terrorists or petty crime, and self-interest, promote covenanted communities in which homeowner associations and deed restrictions impose obligations from paint colour to hours of swimming pool operation.

Lastly however is the intentional route in which attention is directed to matters of civic participation, economic control, and environmental damage causing a deliberate shift to a neighbourhood-based sense of responsibility and obligation. The verdict is still unclear.

\section{References}

[1] Cohen, J.E., Human Population Grows Up, Scientific American, 293 (3), pp. 48-55, September 2005.

[2] Courchene, T. J., Citistates and the State of Cities: Political-Economy and Fiscal-Federalism Dimensions, 2004.

[3] Johns, M., Moment of Grace: The American City in the 1950s, University of California Press: Berkeley, 2003.

[4] Rae, D., City: Urbanism and Its End, Yale University Press; New Haven, 2003.

[5] Donald, B., Economic Competitiveness and Quality of Life in City Regions: compatible concepts?, Canadian Journal of Urban Research, 10 (2), 2001. 
[6] Hall, P. \& Ward, C., Sociable Cities: The Legacy of Ebenezer Howard, John Wiley and Sons: Chichester, 1998.

[7] Gandy, M., Concrete and Clay: Reworking Nature in New York City, MIT Press: Cambridge, p.113, 2002.

[8] Pahl, R.E., (1969) Whose City? And Further Essays on Urban Society, Penguin: Middlesex, p.293, 1969.

[9] Hayden, D., Building Suburbia: Green Fields And Urban Growth, Pantheon Books: New York, 2003.

[10] Chaskin, R.J., Defining Neighborhood: History, Theory and Practice, Chapin Hall Center for Children, University of Chicago: Chicago, 1995.

[11] Keller, S., The Urban Neighborhood, Random House: New York, 1968.

[12] Bradford, N., Place Matters and Multi-Level Governance: Perspectives on a New Urban Policy Paradigm. McGill Institute for the Study of Canada Annual Conference, "Challenging Cities in Canada", February 11-13, 2004.

[13] Katz, B., Neighborhoods of Choice and Connection: The Evolution of American Neighborhood Policy and What It Means for the United Kingdom Metropolitan Policy Program, The Brookings Institution Research Brief, 2004.

[14] Florida, R., The Rise of the Creative Class, New York: Basic Books, 2002.

[15] Putnam, R., Bowling Alone: The Collapse and Revival of American Community, Simon and Schuster: New York, 2000.

[16] United Way - Poverty by Postal Code: The Geography of Neighbourhood Poverty - 1981-2001, A Report Prepared Jointly by United Way of Greater Toronto and the Canadian Council on Social Development, 2001.

[17] Epstein, H., “...Enough To Make You Sick”, New York Times Magazine, October 12, 2003.

[18] Hardy, M., Renaissance of the traditional city, Axess Magazine, retrieved on line 4/5/2004, www.axess.se, 2004.

[19] Jacobs, J., Death and Life of Great American Cities, Random House: New York, 1961.

[20] Riemer, S., Hidden Dimensions of Neighborhood Planning, Land Economics, 26 (2), pp. 197-201, 1950.

[21] Oldenburg, R., The Great Good Place, Marlowe and Company: New York, 1989.

[22] Duany, A., Plater-Zyberk, E., \& Speck, J., Suburban Nation, North Point Press: New York, p.151, 2000.

[23] Sale, K., Human Scale, Perigee: New York, 1980.

[24] Moffatt, S., Closing the Loop: A Guide to Green Infrastructure for Canadian Municipalities, Federation of Canadian Municipalities and the Sheltair Group: Ottawa, 2001. 